Historic, Archive Document

Do not assume content reflects current scientific knowledge, policies, or practices. 
. 
$2,07 \quad 1930$

\section{PRICE LIST OF}

LIBRARY TECETESO

BUSINESS FoUnDED 188 — JAN 1930 *

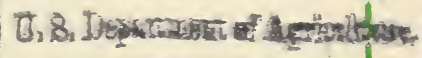

Blue Ribbon Brand Strawberry Plants

\section{FIFTY YEARS OF SUCCESSFUL BUSINESS}

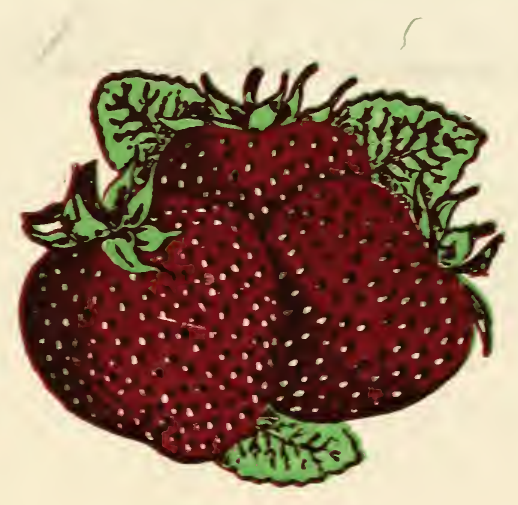

Local and Long Distance Phones

Office 121 - Residence 125

When You Plant Bauer's Blue Ribbon Brand Plants You Plant The Very Best Grown

\section{J. A. Bawer \\ The Strawberry Plant Man}

LOCK BOX 38.

JUDSONIA, ARKANSAS

Reference: Bank of Judsonia, Dun or Bradstreet 


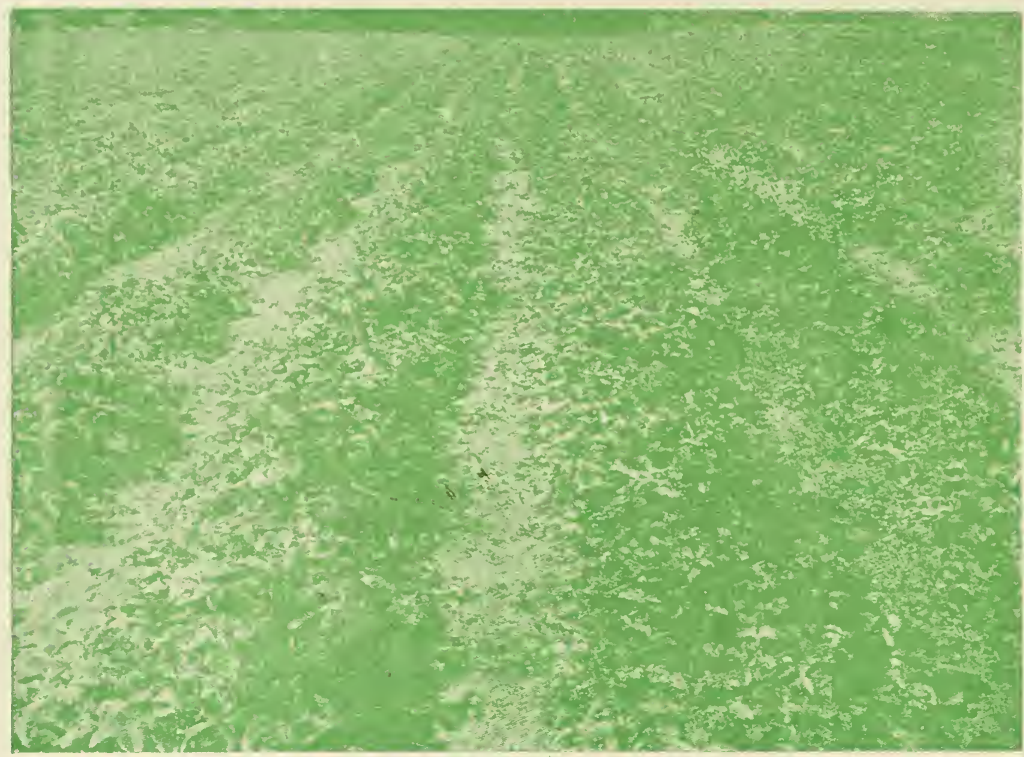

A Block of Our Improved Klondike Berry Plants. When You Set Bauer Plants You Get the Best Grown.

\section{Greetings for 1930}

The past sedson was ver! unfavorable for berry plants, as at was dry a big part of the summer and plants made ferver than usual, but the quality was never so good as this season. In all our experience we have never grown better plants than we have this season

We have a big stock of Missionary and Improved Klondike, and a limited stuck of other common surts In Mastodon we have a good stock and we advise placing of orders for plants very early to assure you of your wants

We can move as many as 500,000 plants per day and we can assure you if weather permits we can get your order off quickly

We hope you can send us some names of prospective patrons to whom we can send our list

We thank one and all for past farors and wish you good luck this season

Every patron must be a pleased patron When you buy Bauer's Blue Rib bon Brand Plants you buy the best grown

Yours for better plants, J. A BAUER 


\section{General Information}

SHIPMENTS- We pack all our plants in slatted crates. W'e guaran. tee sate arrival on all shipments to April with. After that date they iravel dt purchaser's risk. We do not advise any shipments of berry plants by freight as it is not safe; we advise that all shipments he enther hy ex press or mail.

W'e use lots of damp moss to the roots, and plants should arrive as fresh as the day we ship them. We have tested our packing this fall, by letting some four crates stay in the packing house for twenty days and when we unpacked them most all of the plants were still good. Most all of the plants we ship reach our pat. rons in from one to five days, so we know by this test that plants will ar nie any place in good order

TERMS- We ask wash hetore shipment is made or will takic nne half cash and the balance c. o. d., you to pay tor return of 2.0 .4 . You may send sheck if you will add is cents for exihange. or bank draft no money order as you wish

MAIL ORDERS-On our mail or ders we send you just as large plants as if they went by express, and we sell ds few as twenty-five berry plants of one vanety and all we ask is for you to make your order for $\$ 1.00$ or more as we don't fill nrders for less than that amount In casc vou. Wunt plent= sent hy masl, c. o. d for ene half, you will have to pay return of monel and fee for c. o. d sipments. II e guarantee safe arrival hr mail as well as hy express

PROMPT SHIPMENTS-When wou get ready ior your plants what vou want is service and that we have II'e san fach and ship three million plants per week and do it easily; and if you flace your order with us, weather permitting us to dig stock, rou will get quich service and the hest plants grown. When my father, Jacob C. Bacer. started this business in $188 \%$, little did he think that the husiness would grow until it was the largest of its kind in the entire south west, hut such is the case. We ship more plants than any other four irowers inmhined in our section Don torget that if vou have friends wh. want gord plants to pass the - wd word along that we have them

PACKING HOLSE-My paiking huse is hedted one half mile from the express office. $1 H^{\top}$ e get orders off - metimes onc hour after receipt of sme and we use every effort to give nou quick service. So, if you are in d hurry for plants send orders to me and we will do the rest. Every patron must he a pledsed patron. W'e make wu whe if for anv reason you are $n \cap t$ satist.

\section{Descriptions of Varieties}

I don t grow a big list hut everv variety we offer rou does well in the south and snuthwest and we dig up all the rows. We give you the hest plants. All plants we sell were set last spring and we nerer dig up from two sear old heds. Youll make no mis tatie in placing rour order with us.

EXCELSIOR, Per. The very carl. lest herry grown and one which is 
a fine berry for the home. They make a nice, dark red berry which makes the finest of jelly and preserves of any berry grown. We advise all to plant at least some of this grand old variety.

THOMPSON, Per. The old Lady Thompson, improved over the old variety. This variety is firmer; is a good fruiter and will carry well any place. A good plant maker, will stand hot dry summers well. Season is a bout a week later than Excelsior and the Excelsior comes on right after the last frost. They can't be earlier than' the Excelsior. This Thompson variety does well all over the south. west.

MISSIONARY, Per. This berry is the leading sort for the south. They grow them with success in Florida, Alabama and South Texas, and we fill all orders up to million lots and advise the planting of them in above states. Season second early; a good selling berry.

IMP. KLONDIKE, Per. A good all around berry. The one we sell more plants of than any other va. riety of its season. We can furnish them in any amounts wanted. We guarantee satisfaction on all your orders for this grand berry. I intro. duced this berry and know it to be a good berry. Try them.

DUNLAP, Per. This variety does well in the northern and western states. We don't like them for the south as they are not as good as oth. ers of same season in this section. We have the pure stock of them; we can fill all orders.

AROMA, Per. This berry, for its season, sells more than any of the later varieties. We sell more of them each year than all other kinds com. bined for late fruiting We have plenty of the best plants and call fill all orders, large or small Hope to have your Aroma orders.

Gandy, Per. An old late variety, about four days later than Aroma: a good one.

CHAMPION K., Per. A new early berry; large size; very product. ive and a good shipper; they will pay to plant.

ST. LOIUS, Per. The best early berry grown today for home and nearby markets; we know of no bet. ter berry to grow than the St. Louis; yield is greater than any variety we have ever grown for any season of the year. You can make 400 crates per acre from St. Louis. Don't fail to plant them. Originated and intro: duced by me.

EVENING STAR, Per. The best real late berry of all, at least a week later than Aroma; will last a week to ten days after Aroma are gone. Big strong plants, very large berries. We have grown both Evening Star and St. Louis where 12 berries filled a quart well rounded up. Don't fail to plant these two grand new ber. ries; introduced by me.

LADY CORNELLIE, Per. A ber ry grown with success in Florida and one which has commanded the high est market prices

PREMIER, Per. A berry grown with success in the east and north; not so good for the south.

PROGRESSIVE, Per. We have many calls for Progressive Everbear ing. We have a big stock of them and can fill all orders, large or small; guarantee our stock pure and true to name. We can make you better pric. es in 25,000 lots or more.

MASTODON, Per. The greatest everbearing berry grown and one that will please you. Large to very large in size; a sure cropper all sum. mer. 
ROCKINGHAM. Per. This is a grand new late berry that ripons with the Aroma and is a lery pro ductive variets We like them finc This berry is a fine nne fur home markets or fur long distance ship ments either. We have not had a new rariety for yedrs ds guod ds the Rockinsham. Wi consider them ane of the very hest varieties yrown

TEXAS, Per. This is a grand ili variety we hate listed again ds we hale had many in the past two jears who wanted this rariety, and so re have added them to wr list Ther are if scound scason. a litth late: than Excisowr Thoy are great to mathe a second irup through the summer menths. of gocd size, goud flaver and very productice. Don't fall to try them. IV e have the pure stock

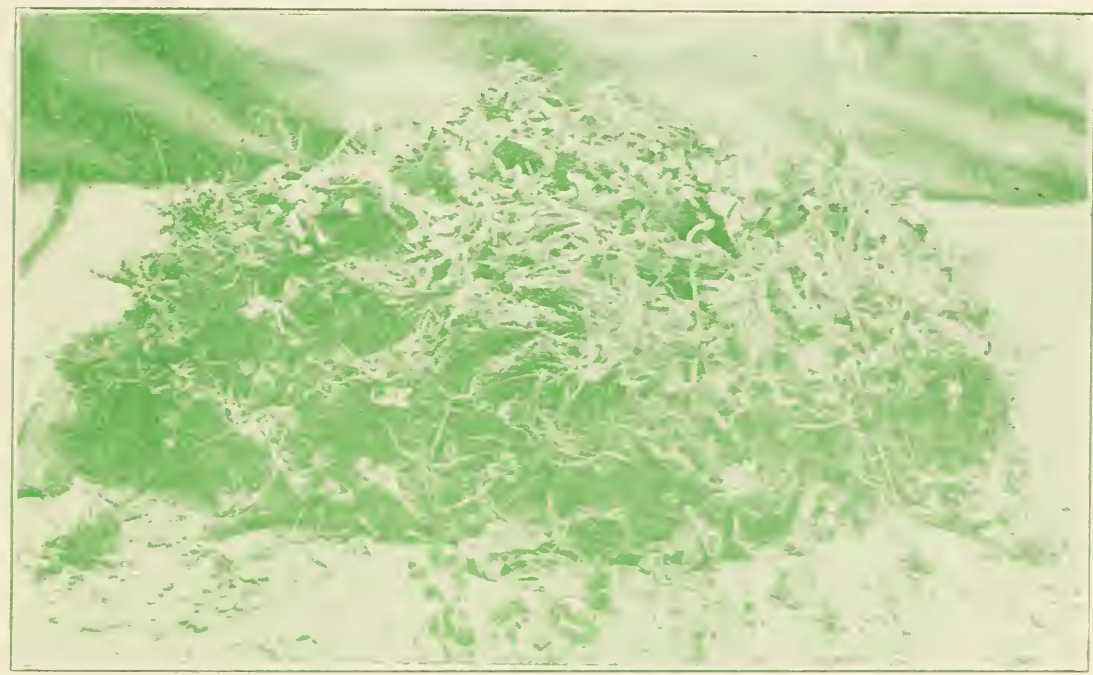

This is a Picture of a Thousand Cheap P'ants

The is the attal phetegraph of a thousdnd planti we brught last spring

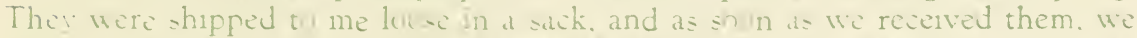
turned them we and had this phutweenh nade of them. Not 20 per cent if this 1.000 flants were worth settmer they were cheap and you can see why

Bauer plants are tied 25 in the bunch. trmmed and picked in damr moss. $\therefore$ atie arrival guaranteed.

Which kind do you think it pays to buy?

\section{The Great Mastodon}

Read these letters from parties to each of whom we sent a crate of bernes this last fall The proof of the pudding is in the eating. This shows that Mas. todon dies well with us; we think they will do well with you. Now, while we have had entire success with them, in no case do we guarantee them to do well 
with others as all we can do is furnish you pure, true blue stock, and you must take the same thance we did on them doing well in your locality.

$$
\begin{array}{r}
\text { Little Rrit. Ark } \\
\text { septemher 27. 1928 }
\end{array}
$$

$\int$ A Baver,

Judsonia, Ark

Dear Mayor:

The rate of bers: = eferred to 13 yom letter if the 25 th arrived in due time and was enjored hy the whole family We thank you for the kind rinemhrance

$$
\begin{aligned}
& \begin{array}{c}
\text { Your friend, } \\
\text { Harrev Parnell. } \\
\text { Governor }
\end{array} \\
& \text { Little Rock, Ark } \\
& \text { septemher 26, } 1928
\end{aligned}
$$

$\int$ A Bduer,

Judsunia, Ark

Dear Sir

W'e are 11 re-ipt of the crate of bermes you sent us and we think them ery fine fur the time of the yedr They reached us in good con dition and were wry much enjoyed hi she antire family We wsh t star in ren for send ning them

$$
\begin{aligned}
& \text { Yours very truly: } \\
& \text { Ios IV V'estal or Jin } \\
& \text { Luttle Rnck. Ark }
\end{aligned}
$$

j A Baver,

$$
\text { Sept 27. 1928 }
$$

Judsonia, Ark

Dear Mr. Bauer,

$\{$ am just in receipt of the crate of berries you sent me They sure are fine for this time of year and sure have the gnod strawberry flawn Pleste accept mi thank for same

Your friend,

W. N. Wilkes,

(oomminsmater of Agricilture

( I he following are clippings trum thr Artansas Democrat of October
Iith. 1ith and 2ith, 1928.)

STRAWBERRIES MAY BE GROWN YEAR AROUND

Since waman as the purveyor of the family table provender is now days fully alive to the value of fresh iruits and vegetables on the bill of tare, her interest is the increasingly nopular everbearing strawberry is int to be wondered at

- A hundred plants in a bit of var den will do wonders in the way of supplying fruit for the small family and at a season of the year when such an "out-of-season" fruit is mos! appreciated.

Fresh home grown strawberries for the Thanksgiving dinner table is something not to be overlooked as a "good thing" and many housewives even in the city, will feel it wise to cast abnut for a small plot for the ercrbearing bed.

The pust week frisnds in Little Rock have been the recipients of small crates of these luscious berries from a well known grower, who sfecializes in this field It is said that berries will probably be gathered by this grower as late as the middle of December, from plants that began bearing last spring

\section{RIPE STRAWBERRIES ON KENSETT MARKE I}

Kensett, Oct. 13- Rupe straw berries were marketed here Wed nesday They sold readily for 25 ents per quart basket. They were of the everbearing variety and are sald to have been raised on the $]$ A. Bauer farm near Judsonia. This 


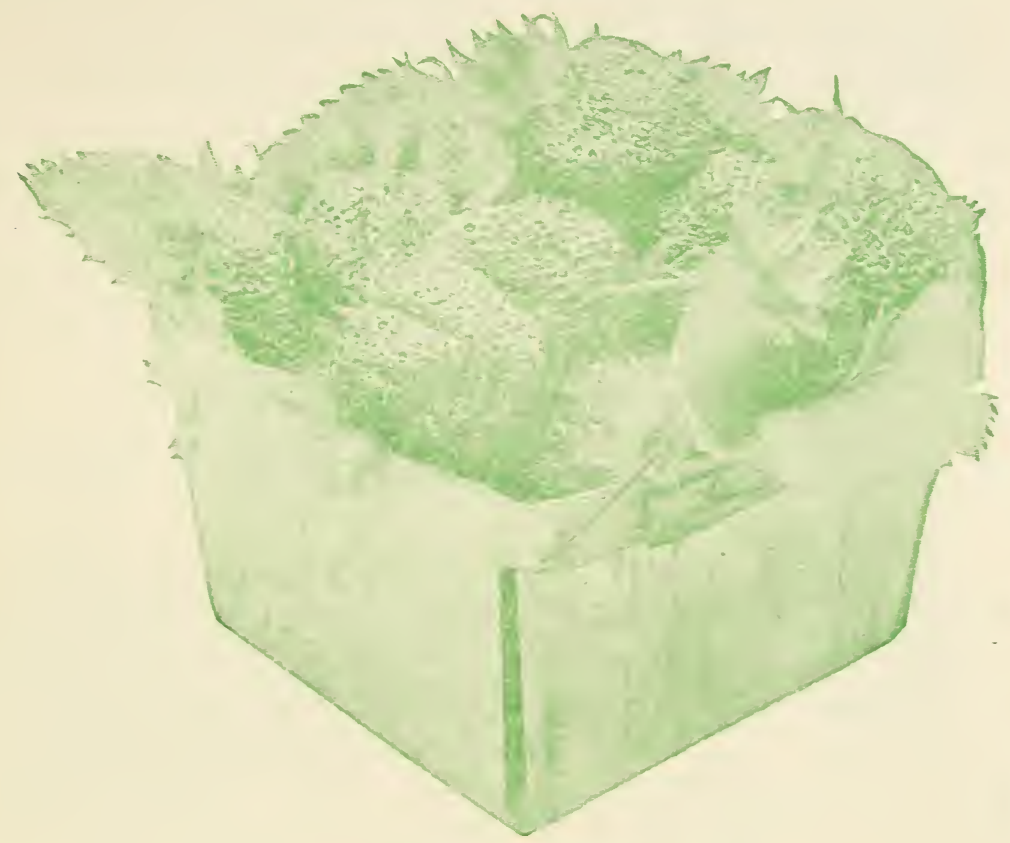

A Quart of Mastodons. Note the Size

is the first time that ripe strawberric: have been on the mirket here this late in the year. It goes to show that two or more crups of berries can be raised here every year and that late berries pay as well or hetter than the early:

In 1878-Jacob C Bauer engaged in growing strawberries and selling plants at Judsonia $H_{1}$ son, J A Bauer is still known as the Strawber ry King, since he is able to sell straw berries almost the year round, as a specialist in the Everbearing berry' Mr Bauer has a display of berries and plants in bloom and in fruit at the Arkansas State Fair, which is at tracting much attention, especially a. mong women interested in flower and vegetable gardening

Fifty to 75 plants planted in good soil as a border to a flower bed will pridice enough fruit for a small tamily, Mr Bauer said. The Ever bearing strawberry begins to bear eariy in the spring and continues to produce berres until late fall. Last year, Mr. Buter gathered his last herries for the season on December 10. The plants will bloom and bear until the temperature goes down to ten above zero. Mr. Bauer ships plants and herries to all parts of the country

Now, after reading all this, if you are still in doubt that Mastodon will fruit all summer and fall, you may come next summer as my guest and we can show you ripe fruit, green fruit and blossoms on the vines all at one time.

We are limited on supply of this grand new berry. Demand is greater 
ath year than the supply. We advise you to place your orders early and ive advise you to he careful with whom you place orders, for many sell common sorts for Mastodon. We suarantee pure stock and can fill ail wders to April 1jth, we feel sure.

IVe hope to have your orders for them. We have much more copy on this variety that we haven t room for hut this should convince dnyone that they are crerbearing berries

The Mastodon have grown so big that 18 berrics filled a yuart box well rounded. The flavor is as good ds any spring variety. We can't say toc) much for them and 25 plants will give you a start with them.

\section{Price List of Strawberry Plants}

All lots of $2 i$ to 100 we send post paid at prices named and all hots of zic and up are shipped express collect.

\begin{tabular}{|c|c|c|c|c|c|c|c|c|}
\hline & ( & ost & aid & ( & \multicolumn{4}{|c|}{ Express Collect } \\
\hline \& Variety & 25 & 50 & 100 & 250 & 500 & 1,000 & 5,000 & $10,0($ \\
\hline Excelsior, Pér & 40 & 65 & $\$ 1.00$ & $\$ 1.00$ & $\$ 1.75$ & $\$ 2.75$ & $\$ 12.50$ & $\$ 24$ \\
\hline Imp. Klondike, Per. & $4 n$ & $6 i$ & 1.00 & 1.00 & 1.75 & 2.75 & 12.50 & \\
\hline Aissionary, Per. & 40 & 65 & 1.00 & 1.00 & 1.75 & 2.75 & 12.50 & \\
\hline nlap, Per. & 4) & 65 & 1.00 & 1.00 & 1.75 & 275 & 12 & \\
\hline ompson, Per. & i(1) & $y()$ & $1.2 i$ & 1.2 & 2.00 & 3.25 & 15 & \\
\hline md, Per. & 5() & 9() & 1.25 & 1.2 & 2.00 & 3.00 & 0 & 27 \\
\hline idy, Per. & 50 & 9() & 1.25 & 1.2 & 2.00 & $\therefore 2 ;$ & 0 & \\
\hline ockingham, Per & in & 90 & 1.25 & 1.25 & 2.00 & $\therefore 2 i$ & $15,0()$ & \\
\hline hampion K, Per. & :0) & 90 & 1.25 & 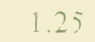 & 2.00 & $\therefore 2 i$ & () & \\
\hline t Louis, Per, & $5(1)$ & 9() & 1.27 & 1.25 & 2.00 & $\therefore 25$ & 15.00 & \\
\hline Vening Star, Per. & 50 & 90 & $1.2=$ & $12=$ & 2.00 & $\therefore .2=$ & 15.0() & $2-$ \\
\hline Cornellic, Per. & 50 & 90 & 1? & & 2.00 & $\therefore 27$ & & 27 \\
\hline remier, Per. & 50 & 90 & 1.25 & $1.2=$ & 2.00 & $\therefore 2 i$ & $1=.100$ & $2-$ \\
\hline Per. & $=0$ & $90^{\circ}$ & 1.25 & & 2.00 & $\therefore 27$ & 15.161 & $2^{-}$ \\
\hline ssive, Per. & .75 & 1.100 & 1.75 & & 3.50 & $6.011)$ & 27.5() & il) \\
\hline fiastodon, Per. & $1 .(10)$ & 1.40 & 2.0() & 3.50 & 7.00 & $1:$ i & $\theta(1.0)$ & I \\
\hline
\end{tabular}

All of the ahove are perfect bloommg varietics. We ask that wou order plants as priced above. We do not allow you to make up an order of infir of threc different kinds at these prices, but sell each variety at price listed. all of the one kind. If you have a mixed order you wish prices on, send rour list for special prices. In making out your order write very planly ds we only have your writing to go by and many times it is so dim or so hard to read we get the name wrong, so we ask you as a favor to write planly: While my list is not large yet all are a success in the southwest and you will make mo mistake in planting any of the varicties we list.

\section{TRY OUR BRED UP MISSIONARY PLANTS}

We have a fine lot of Missionary plants, bred up to make big crops.
We have one customer in Alabama who sold $\$ 1,800.00$ worth of berries 
from two acres of our Missionary last spring. Think of it! \$9 o .010 per acre. You can not go wrong if you set Bauer's plants. WVe have many patrons who have cleared as much or more than this man did from berries we furnished the plants for

We feel sure you want the best plants grown; we have priced them right and can ship promptly any or der you give us.

\section{Horseradish Roots}

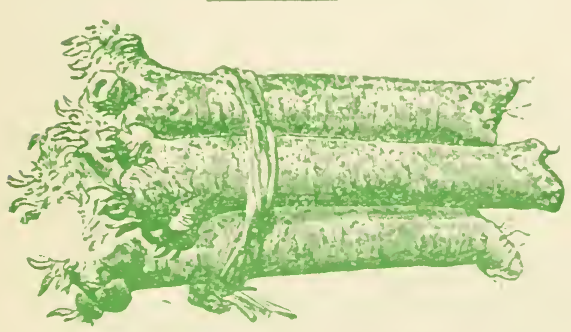

We have the Maliner variety. This is fine for growing in yrour garden for making sauce and it will stand hard winters. 10, \$1.00: 25, \$1.75: $50, \$ 250: 100 . \$ 4.00$

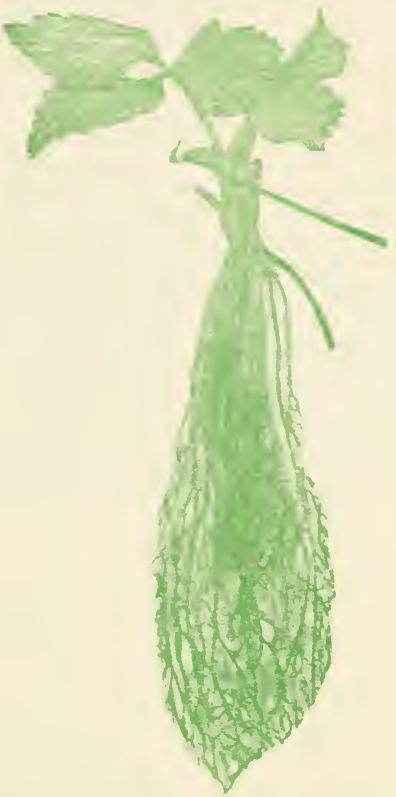

One of Our Strawberry Plants Trimmed, Ready for Bunching

We bunch 25 in a bunch; we pack in damp moss; we guarantee safe ar. rival on all plants, either by mail or express

\section{Frost Proof Cabbage Plants}

We have our cabbage plants grown in South Texas and we have sold them for several years and have found them very satisfactory in ev. ery way. Varieties are Early Jersey Wakefield, Charleston Wakefield,
Flat Dutch, Succession, Copenhagen. We offer in irates of 3,000 plants. Per crate, $\$ 3.90$, f. o. b. shipping point. We don't fill orders for less than crate lots

This season we will ship all Onion and Cabbage plants in crate or basket lots direct from our growers. We price them f. o. b. shipping point in South Texas. We shipped plants last winter when most every grower had his stock frozen out for some time. We filled all orders as we have our plants grown far enough south where they don't freeze out. We hope to have your orders for these plants. 


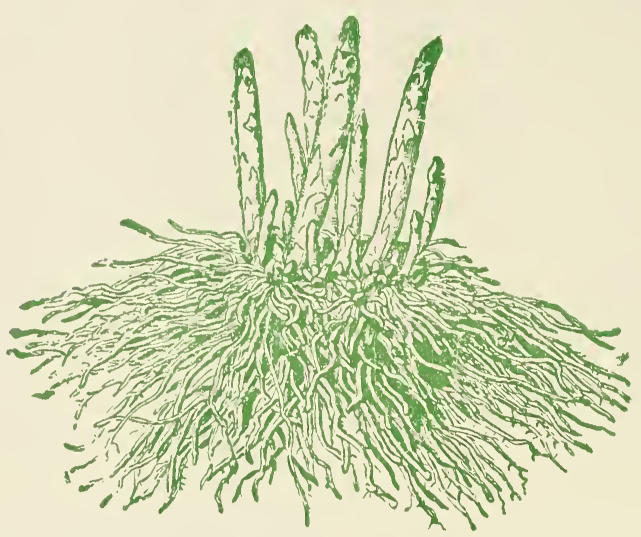

\section{Asparagus Roots}

We have one yedr old roots. We ship post paid in lots of 10 to 100 Over that amount we ship express collect. We can give you Palmetto at the fol. lowing prices: $10, \$ 1.00 ; 25$, $\$ 2.00 ; \quad 50, \$ 3.00 ; 100, \$ 4.25$; $250, \$ 4.25 ; ; 00, \$ 7.50 ; 1,000$, $\$ 1+.00$.

\section{Rhubarb Roots}

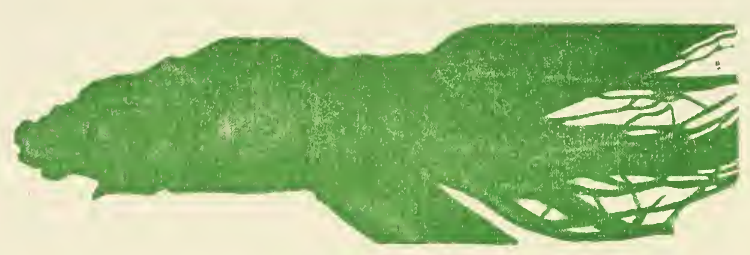

We can furmsh you this grand garden plants, one of the very earliest things to come on for pies or relishes and it is a good tonic for anyone.
We furnish you 1 year, divided roots, variety Victoria, $10, \$ 1.50 ; 25, \$ 2.50$; $50, \$ 3.00 ; 100, \$ 4.25 ; 250, \$ 10.00$; $500, \$ 15.00$

\section{Onion Plants}

Yellow Bermuda and Crystal White Wax. Fine, well grown, pen cil size plants, 6,000 to the crate at cil size plants, 6,000 to the crate.

Crate lots all of one kind, $\$ 4.00$; 5 crate lots, $\$ 3.40 ; 10$ crate lots, 60,000 plants, $\$ 3.00$ per crate, f. o. b. shipping point. You must order full crate lots of one kind to get these prices.

We do not fill orders for less than crate lots. We guarantee safe arrival on all stock and we can ship any day now you want, cither cab. hage or onion plants. My grower is one of the best growers in Texas; we have found him honest and we know that he grows good plants. We can fill orders very promptly and accept all orders subject to freezing weather getting plants, as we have no control over weather conditions. 


\section{Sweet Potato Plants}

Wic grus and ship mans, fut fant we shif into the tollowing states only: Missouri, Nebraska, Kansas, Illinois, Kentucky, Tennessee, Alabama, Texas and Arkansas. If you dor't live in one of these states we can t handle your order Prices made are delitered to your post office

We offer Nancy Hall and Long Vine Porto Rican plants at the following

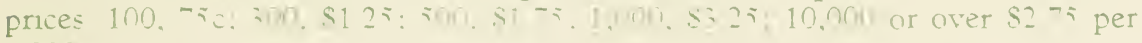
$1.0 n 0$

We has d fine new putati wh the Butich Purto Rican: very tine flavored,

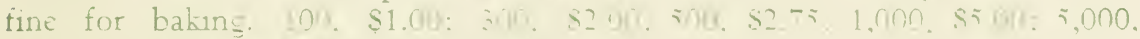
\$2 250: 10, rom, $\$+010 y$ All post paid

We use the best of care in sele-ting the potatnes we bed we get the best seed stock we can grow or bur. ITe statt shipments March löth and shif to

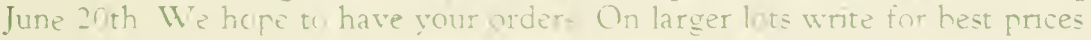

\section{A Few More Words, Please, About Our Plants}

I know you will receive many price lists and catalogues and all will tell you they grow the best plants. What I want to tell you is that my plants are so large we pack from 1,500 to 2,000 in bushel crates. We have seen many where they pack 3,500 in the same sized crate, yet they will tell you they have the best plants grown. Plants are measured by the size they grow. We have the best and largest plants grown; none of them grown on worn out lands but on new lands and lands not under cultivation over four or five years. This grows big, strong, well-rooted, vigorous plants and the kind I know you want. Now. If you have never tried Bauer's Blue Ribbon Brand Plants you had better dc so this spring and get the best plants grown at a fair price.

Another thing we wish to impress on your mind is that we can fill an order, regardless of its size. We are now filling an order for 2,000,000 Improved Klondike berry plants for the State of Alabama. They wanted the best plants they could get, so they are planting Bauer's Blue Ribbon Brand plants. We take the same pains with small orders that we do with larger ones and guarantee satisfaction with every order. You must be a pleased patron and if for any reason any transaction you have with us is not satisfactory, all we ask is a chance tc make it satisfactory; we aim to please every patron

We are well stocked on Improved Klondike, and Missionary. These are the two leading standard varieties. We can fill any order you may place with us for them. Again thanking all for past favors and with the hope of receiving your order again this spring, I await your commands

\section{J. A. B A UER}

Lock Box 38.

Judsonia, Arkansas 


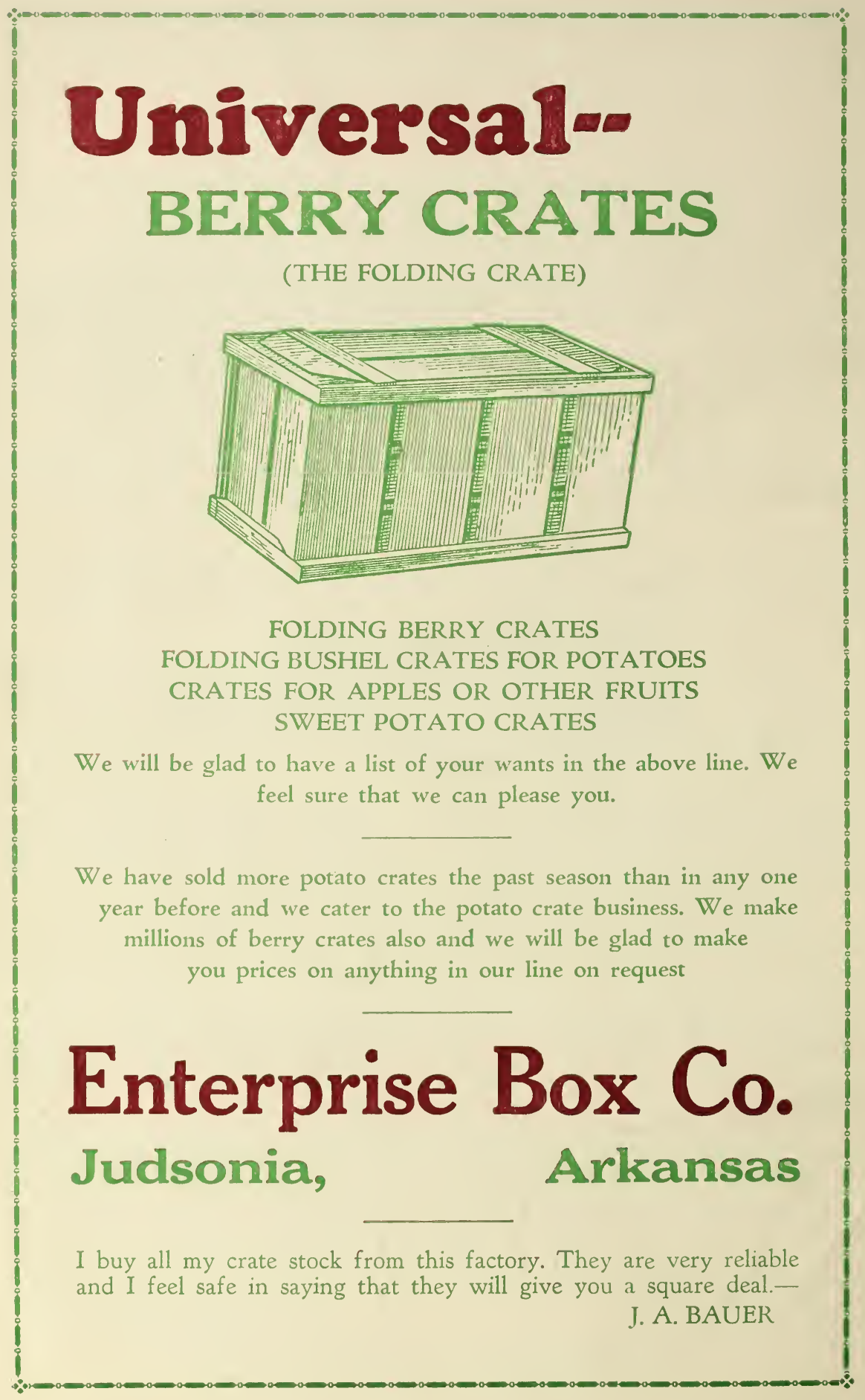

